\title{
Electrocatalytic properties of platinum nanocenters electrogenerated at ultra-trace levels within zeolitic phosphododecatungstate cesium salt matrices
}

\author{
Aneta Kolary-Zurowska • Artur Zurowski • \\ Sonia Dsoke • Beata Dembinska • Sylwia Zoladek • \\ Malgorzata Kiliszek • Roberto Marassi • \\ Pawel J. Kulesza
}

Received: 24 May 2014 / Accepted: 7 June 2014 / Published online: 19 June 2014

(C) The Author(s) 2014. This article is published with open access at Springerlink.com

\begin{abstract}
A unique preparation method of obtaining stable composite film (with ultra-low platinum content) highly active towards oxygen reduction and hydrogen oxidation is presented here. The matrix for platinum centers consists of highsurface-area zeolite-type acidic salt of cesium phosphododecatungstate $\left(\mathrm{Cs}_{2.5} \mathrm{H}_{0.5} \mathrm{PW}_{12} \mathrm{O}_{40}\right)$ admixed with carbon (Vulcan XC-72) carriers. Platinum nanoparticles were deposited on the working electrode modified with matrix via corrosion of platinum counter electrode during cyclic voltammetry experiment conducted in acid electrolyte containing chloride ions. The results obtained from rotating disk voltammetry revealed that the composite film containing Pt nanoparticles at very low loadings (on the level of $2-5 \mu \mathrm{g} \mathrm{cm}^{-2}$ ) demonstrated remarkable electrocatalytic activity towards both oxygen reduction and hydrogen oxidation, particularly, when compared to the performance of the $\mathrm{Cs}_{2.5} \mathrm{H}_{0.5} \mathrm{PW}_{12} \mathrm{O}_{40^{-}}$ free system (i.e., containing only Vulcan support) prepared and examined under analogous conditions. The phenomenon should be primarily ascribed to the mesoporous nature of the matrix enabling immobilization and stabilization of small catalytic nanoparticles (1-2 $\mathrm{nm}$ diameters) inside the pores as well as to high surface acidity of the polyoxometalate-based salt providing proton-rich environment at the electrocatalytic interface.
\end{abstract}

A. Kolary-Zurowska $\cdot$ A. Zurowski $\cdot$ B. Dembinska $\cdot$ S. Zoladek $\cdot$ M. Kiliszek • P. J. Kulesza $(\square)$

Department of Chemistry, University of Warsaw, Pasteura 1, PL-02-093 Warsaw, Poland

e-mail: pkulesza@chem.uw.edu.pl

S. Dsoke $\cdot$ R. Marassi $(\bowtie)$

Department of Chemistry, University of Camerino, S. Agostino 1, I-62032 Camerino, Italy

e-mail: roberto.marassi@unicam.it
Keywords Heteropolytungstate cesium acid salt . Mesoporous reactive matrix · Platinum nanoparticles . Electrocatalysis $\cdot$ Oxygen reduction $\cdot$ Hydrogen oxidation

\section{Introduction}

Platinum is so far the most effective electrocatalytic system with respect to its high activity towards reduction of oxygen [1-5] and oxidation of hydrogen [6-10]. Nevertheless, due to high cost of the noble metal, there has been growing interest in minimizing platinum content and development of materials containing highly dispersed platinum nanoparticles that can provide large surface areas necessary for efficient heterogeneous electrocatalysis [11-14]. One of possible approaches to achieve this goal is to utilize robust conducting (electronically and ionically) matrices (e.g., certain metal oxides) which are capable of immobilizing and separating physically catalytic metal centers thus reducing their rate of agglomeration and degradation. Obviously, an ideal matrix for heterogeneous electrocatalysis would interact specifically with dispersed noble metal centers to affect their structural, electronic, chemisorptive, and interfacial properties [15-18].

With respect to the reduction of oxygen, a good matrix (support) should also be reactive towards reduction of hydrogen peroxide (i.e., the undesirable oxygen reduction intermediate). For instance, tungsten oxide was demonstrated to activate traces of dispersed platinum and promote oxygen reduction through the existence of metal-support interactions [17, 18] leading to the hydrogen spillover and formation of highly conductive hydrogen tungsten oxide bronzes [12-16, 19] reactive towards reduction of hydrogen peroxide $[12,13]$. The enhancement phenomenon in the oxygen reduction was also observed when Pt-based electrocatalysts were modified 
with ultra-thin films of heteropolytungstates [20-22] (which can be considered as electrochemical analogs of tungsten oxides) which are known for fast electron and proton transfer capabilities [20,23]. Adsorption of $\mathrm{H}_{3} \mathrm{PW}_{12} \mathrm{O}_{40}$ on Pt resulted in the positive shift of the surface voltammetric peaks related to the formation of Pt-oxo (PtOH or PtO) species [22] thus enlarging the potential window where bare metallic Pt sites (e.g., for adsorption and activation of oxygen molecules) existed. Further, interactions between heteropolyanions and $\mathrm{Pt}$ surface atoms were demonstrated to involve mostly corner oxygen atoms (from heteropolyanions) and only a few percent of interfacial reactive platinum atoms were believed to be blocked with respect to the access of oxygen molecules [22].

Tungsten heteropolyacids were considered for fuel cell research as both catalysts [24-26] and membrane compounds [27-30] but most of them were readily soluble in acid media and tended to be desorbed from Pt surface during the longterm operation of the systems. Therefore, there is a need to increase polyoxometalates overall stability and interfacial rigidity.

It has been recently established that salts of heteropolyacids may be produced by partial exchange of protons in parent heteropolyacid with a small $\left(\mathrm{Li}^{+}, \mathrm{Na}^{+}\right)$or large $\left(\mathrm{Cs}^{+}, \mathrm{Rb}^{+}, \mathrm{K}^{+}\right.$, $\mathrm{NH}_{4}{ }^{+}$) cation [31]. The resulting systems are characterized by different solubility and morphology in comparison to the parent heteropolyacid structures [32-35]. For example, the partial exchange of protons in $\mathrm{H}_{3} \mathrm{PW}_{12} \mathrm{O}_{40}$ with $\mathrm{Cs}^{+}$cations transforms the water-soluble acid into the water-insoluble acid salt, $\mathrm{Cs}_{2.5} \mathrm{H}_{0.5} \mathrm{PW}_{12} \mathrm{O}_{40}$. Further, the surface area of the latter system $\left(100 \mathrm{~m}^{2} \mathrm{~g}^{-1}\right)$ is much higher than that of $\mathrm{H}_{3} \mathrm{PW}_{12} \mathrm{O}_{40}$ $\left(<5 \mathrm{~m}^{2} \mathrm{~g}^{-1}\right)$. The increase of $x$ (i.e., the Cs content) in $\mathrm{Cs}_{x} \mathrm{H}_{3-}$ ${ }_{x} \mathrm{PW}_{12} \mathrm{O}_{40}$ from 0 to 2 results in lowering the population of surface protons, but their availability significantly enlarges when $x$ is changed from 2 to 3 ; the system shows the highest surface acidity at $x=2.5$. Thus acidic strength of $\mathrm{Cs}_{2.5} \mathrm{H}_{0.5} \mathrm{PW}_{12} \mathrm{O}_{40}$ is similar to that of $\mathrm{H}_{3} \mathrm{PW}_{12} \mathrm{O}_{40}$ [32, 35, 36]. Further, membranes composed of $\mathrm{Cs}_{2.5} \mathrm{H}_{0.5} \mathrm{PW}_{12} \mathrm{O}_{40}$ and Nafion (relative to plane Nafion) exhibit superior stability against oxidative agents and better performance in PEMFCs [37-39]. It has also been suggested that $\mathrm{Cs}_{2.5} \mathrm{H}_{0.5} \mathrm{PW}_{12} \mathrm{O}_{40}$ present in the membrane acts as active catalyst towards $\mathrm{H}_{2} \mathrm{O}_{2}$ decomposition [38, 39]. Co-precipitation or simple admixing of $\mathrm{Cs}_{2.5} \mathrm{H}_{0.5} \mathrm{PW}_{12} \mathrm{O}_{40}$ with Pt-Co alloys results in the improved electrocatalytic performance toward oxygen reduction [40]. Moreover, similar enhancement effect was observed after impregnation of such matrix with chloroplatinic acid followed by its chemical or electrochemical reduction [41].

In the present work, we describe a unique preparation method and discuss electrocatalytic properties (towards oxygen reduction and hydrogen oxidation) of composite utilizing the $\mathrm{Cs}_{2.5} \mathrm{H}_{0.5} \mathrm{PW}_{12} \mathrm{O}_{40}$ salt functioning as stable and active matrix for highly dispersed platinum nanocenters (at ultratrace level) obtained via anodic dissolution (corrosion) of the platinum counter electrode $[13,42-44]$. Since heteropolytungstates are better catalysts for reduction of oxygen than their molybdenum counterparts [20-22], we have focused here exclusively on the tungsten-containing compound. The addition of carbon nanoparticles (Vulcan XC72) has ensured good electronic conductivity of the catalytic layer. The main advantages of the utilized salt are as follows: high surface acidity and presence of mobile protons in the vicinity of catalytic centers, mesoporous morphology, and ability to entrap very small catalytic nanoparticles (ca. 1$2 \mathrm{~nm}$ diameters). The reactivity of $\mathrm{Cs}_{2.5} \mathrm{H}_{0.5} \mathrm{PW}_{12} \mathrm{O}_{40}$ towards reduction (decomposition) of hydrogen peroxide may also result in dimishing of the formation of undesirable $\mathrm{H}_{2} \mathrm{O}_{2}$ intermediate.

\section{Experimental}

The electrochemical measurements were carried out in a threeelectrode cell utilizing a platinum flag as the counter-electrode and a saturated calomel electrode (SCE) as the reference electrode (placed in a separate compartment and connected to the main cell by a Luggin capillary). A rotating glassy carbon disk electrode of $0.1256 \mathrm{~cm}^{2}$ surface area was used as the working electrode. Before deposition of catalytic layers, the glassy carbon disk electrode substrate was polished on a cloth wetted with aqueous suspension of $\mathrm{Al}_{2} \mathrm{O}_{3}$ (particle size,

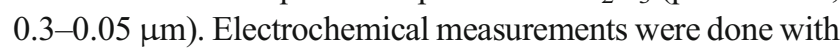
$\mathrm{CH}$ Instrument Model 660 B workstation. Rotating disk electrode voltammetric measurements were executed using a variable speed rotator from Pine Instruments. All measurements were carried out at room temperature $22 \pm 2{ }^{\circ} \mathrm{C}$. As a rule, all potentials were expressed vs. RHE.

Heteropolytungstic acid $\left(\mathrm{H}_{3} \mathrm{PW}_{12} \mathrm{O}_{40}\right)$ was obtained from Fluka. Salt of cesium nitrate $(\mathrm{V})$ was from Aldrich. Vulcan XC-72 carbon nanoparticles were purchased from E-TEK. Nafion ${ }^{\circledR}$ (5\% alcoholic solution) was from Ion Power, and ethanol ( $>99.9 \%$ ) was from Baker. Electrolytes were prepared using $\mathrm{H}_{2} \mathrm{SO}_{4}$ of $99.999 \%$ purity (Aldrich). All solutions were prepared using ultra-pure water (Millipore Milli-Q).

The cesium salt of heteropolytungstic acid was prepared using the procedure described earlier [42, 45, 46] by adding dropwise the stoichiometric quantity of the aqueous solution of $\mathrm{Cs}^{+}$to the water solution of heteropolyacid $\left(\mathrm{H}_{3} \mathrm{PW}_{12} \mathrm{O}_{40}\right)$ at room temperature. The resulting suspension was kept under stirring for $24 \mathrm{~h}$ at room temperature. Then the sediment was washed four times with ultra-pure water, separated from the liquid phase by centrifuging, and finally, freeze-dried at $75^{\circ} \mathrm{C}$.

In order to prepare electrocatalytic systems, the electrode substrate was modified with the $\mathrm{Cs}_{2.5} \mathrm{H}_{0.5} \mathrm{PW}_{12} \mathrm{O}_{40}$-containing matrix $\left(\mathrm{Cs}_{2.5} \mathrm{H}_{0.5} \mathrm{PW}_{12} \mathrm{O}_{40}\right.$ /Vulcan) followed by electrodeposition of $\mathrm{Pt}$ nanoparticles. The ink of support (matrix) was prepared by subjecting $\mathrm{Cs}_{2.5} \mathrm{H}_{0.5} \mathrm{PW}_{12} \mathrm{O}_{40}$ together with 
Vulcan carbon nanoparticles and ethanol to magnetic stirring for $12 \mathrm{~h}$. Later, a known amount of Nafion $(5 \%$ alcoholic solution) was added and stirring was continued for another $12 \mathrm{~h}$. The best catalytic results were obtained when the mass ratio of $\mathrm{Cs}_{2.5} \mathrm{H}_{0.5} \mathrm{PW}_{12} \mathrm{O}_{40}$ to Vulcan and Nafion was 2:1:1.1. To conduct comparative studies, ink of $\mathrm{Cs}_{2.5} \mathrm{H}_{0.5} \mathrm{PW}_{12} \mathrm{O}_{40^{-}}$ free Vulcan support was also prepared in similar to justdescribed manner. To immobilize a matrix (support) of either $\mathrm{Cs}_{2.5} \mathrm{H}_{0.5} \mathrm{PW}_{12} \mathrm{O}_{40} /$ Vulcan or Vulcan, $3.5 \mu \mathrm{l}$ aliquot of the appropriate ink was dropped on the rotating disk electrode (RDE). Then the layer was left for $30 \mathrm{~min}$ to dry at room temperature. Typical loadings of supports were in the range of $70-75 \mu \mathrm{g} \mathrm{cm}^{-2}$. The layer of $\mathrm{Cs}_{2.5} \mathrm{H}_{0.5} \mathrm{PW}_{12} \mathrm{O}_{40} /$ Vulcan matrix and (for comparison) monolayer of phosphotungstic acid adsorbed on Vulcan $\left(\mathrm{H}_{3} \mathrm{PW}_{12} \mathrm{O}_{40}(\mathrm{ML}) /\right.$ Vulcan $)$ were also subjected to preliminary voltammetric characterization. In the latter case, GC electrode modified with Vulcan film, prepared in similar to described above manner but containing only $5 \%$ of Nafion (by weight), was immersed in $10 \mathrm{mmol} \mathrm{dm}^{-3}$ solution of $\mathrm{H}_{3} \mathrm{PW}_{12} \mathrm{O}_{40}$ for $30 \mathrm{~min}$ followed by rinsing with water. Such low quantity of Nafion in the sample enables permanent attachment of the layer to GC electrode and simultaneously leaves a lot of free space on Vulcan surface for adsorption of phosphotungstic acid.

Electrodeposition of platinum (from corroded Pt flag counter electrode) into $\mathrm{Cs}_{2.5} \mathrm{H}_{0.5} \mathrm{PW}_{12} \mathrm{O}_{40} /$ Vulcan (or bare Vulcan) matrix was achieved by applying potential cycling $(2,500 \mathrm{cy}-$ cles) from -0.05 to $1.05 \mathrm{~V}$ at the scan rate of $50 \mathrm{mV} \mathrm{s}^{-1}$ in $0.5 \mathrm{~mol} \mathrm{dm}^{-3} \mathrm{H}_{2} \mathrm{SO}_{4}$ containing $5 \mathrm{mM} \mathrm{KCl}$. The presence of chlorides facilitated anodic dissolution of platinum [45]. It should be stressed that under our experimental conditions, in applied potential window, platinum was neither deposited when the carbon paper was employed as the counter electrode $[43,44]$ nor when $\mathrm{KCl}$ was absent in the electrolyte. Following deposition of platinum, an electrode covered with the catalytic layer ( $\mathrm{Pt}_{-}-\mathrm{Cs}_{2.5} \mathrm{H}_{0.5} \mathrm{PW}_{12} \mathrm{O}_{40} /$ Vulcan or Pt-Vulcan) was washed out with water and subjected to cycling in $0.5 \mathrm{~mol} \mathrm{dm}^{-3} \mathrm{H}_{2} \mathrm{SO}_{4}$ in the potential range from 0 to $1.05 \mathrm{~V}$ vs. RHE to remove $\mathrm{Cl}^{-}$from the catalytic film.

Active surface area and, indirectly, loading of platinum nanoparticles was probed using CO-stripping voltammetric approach [47, 48]. Prior to the diagnostic electrochemical measurements, argon was purged through $0.5 \mathrm{~mol} \mathrm{dm}^{-3}$ sulfuric acid electrolyte for $30 \mathrm{~min}$. Then five consecutive cyclic voltammograms were recorded at $20 \mathrm{mV} \mathrm{s}^{-1}$ in the potential range 0.025 to $1.125 \mathrm{~V}$. Later, pure $\mathrm{CO}$ was first bubbled through the electrolyte for $10 \mathrm{~min}$; the actual adsorption of $\mathrm{CO}$ at the electrode surface was achieved upon application of $0.1 \mathrm{~V}$ for $4 \mathrm{~min}$. Further, while keeping the electrode potential at open circuit, argon was purged through electrolyte for 35 min to remove the excess of $\mathrm{CO}$ reversibly adsorbed at the electrode surface. The stripping (CO-oxidation) voltammograms were recorded at $20 \mathrm{mV} \mathrm{s}^{-1}$ scan rate in the potential range from 0.025 to $1.125 \mathrm{~V}$.

The morphology of platinum particles was monitored using a JEM-2100 F electron microscope (TEM) operating at $200 \mathrm{kV}$. Samples were prepared on grids from alcoholic suspensions obtained through immersing of working electrodes modified with catalytic layers in ethanol which resulted in dropping the layers off the surface.

\section{Results and discussion}

Figure 1(a) presents cyclic voltammetric response of $\mathrm{Cs}_{2.5} \mathrm{H}_{0.5} \mathrm{PW}_{12} \mathrm{O}_{40}$ mixed with Vulcan (deposited on glassy carbon electrode) recorded in argon-saturated $0.5 \mathrm{~mol} \mathrm{dm}^{-3}$ $\mathrm{H}_{2} \mathrm{SO}_{4}$ at $50 \mathrm{mV} \mathrm{s}^{-1}$ scan rate. For comparison, cyclic voltammogram of $\mathrm{H}_{3} \mathrm{PW}_{12} \mathrm{O}_{40}$ monolayer, which has been spontaneously adsorbed on the GC electrode covered with Vulcan is also presented (Fig. 1(b)). Electrochemical characteristics of $\mathrm{Cs}_{2.5} \mathrm{H}_{0.5} \mathrm{PW}_{12} \mathrm{O}_{40}$ layer and monolayer of $\mathrm{H}_{3} \mathrm{PW}_{12} \mathrm{O}_{40}$ deposited on bare $\mathrm{GC}$ electrode were reported elsewhere [20, 23, $49,50]$. For $\mathrm{H}_{3} \mathrm{PW}_{12} \mathrm{O}_{40}(\mathrm{ML}) /$ Vulcan (Fig. 1(b)), two sets of highly reversible peaks (characterized by mid-peak potentials at ca. 0.15 and $-0.11 \mathrm{~V}$ ) correspond to two consecutive reversible one-electron processes characteristic for $\mathrm{H}_{3} \mathrm{PW}_{12} \mathrm{O}_{40}$ [21-23]:

$\mathrm{PW}_{12}^{\mathrm{VI}} \mathrm{O}_{40}^{3-}+n \mathrm{e}^{-}+n \mathrm{H}^{+} \leftrightarrow \mathrm{H}_{n} \mathrm{PW}_{n}^{\mathrm{V}} \mathrm{W}_{12-n}^{\mathrm{VI}} \mathrm{O}_{40}^{3-}$

where $n$ is equal to 1 or 2 . Voltammetric response characteristic for $\mathrm{Cs}_{2.5} \mathrm{H}_{0.5} \mathrm{PW}_{12} \mathrm{O}_{40}$ /Vulcan (Fig. 1(a)) is somewhat different. Partial substitution of protons in primary acid with cesium cations results in decay of two well-defined redox signals and only a single pair of drawn-out peaks at the midpeak potential of ca. $0.066 \mathrm{~V}$ can be observed. The potential of the process characteristic for cesium salt is shifted towards more negative values (of c.a. $65 \mathrm{mV}$ ) with respect to the first peak of the parent acid which stays in accordance with

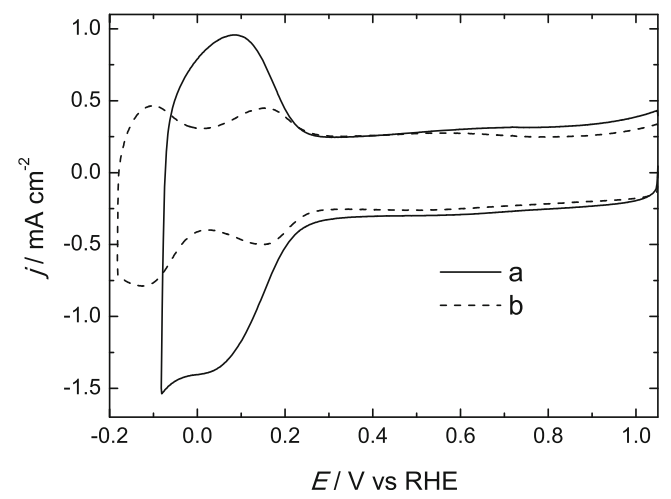

Fig. 1 Cyclic voltammetric responses recorded for the following layers: (a) $\mathrm{Cs}_{2.5} \mathrm{H}_{0.5} \mathrm{PW}_{12} \mathrm{O}_{40}$ /Vulcan and $(b) \mathrm{H}_{3} \mathrm{PW}_{12} \mathrm{O}_{40}$ monolayer adsorbed on Vulcan deposited onto a $\mathrm{GC}$ electrode substrate. Electrolyte, nitrogensaturated $0.5 \mathrm{~mol} \mathrm{dm}^{-3} \mathrm{H}_{2} \mathrm{SO}_{4}$. Scan rate, $50 \mathrm{mV} \mathrm{s}^{-1}$ 
previous reports [41]. It is worth to mention that addition of Vulcan nanoparticles to cesium heteropolytungstate salt considerably improves its electron conductivity; consequently, the dependence of the anodic peak current density (at ca. $0.08 \mathrm{~V}$ ) versus scan rate has been observed until at least $300 \mathrm{mV} \mathrm{s}^{-1}$ (for simplicity data not shown here). Further, also higher symmetry of the redox peaks (Fig. 1(a)) has been observed for the Vulcan-containing system when compared to the electrochemical characteristics of the bare $\mathrm{Cs}_{2.5} \mathrm{H}_{0.5} \mathrm{PW}_{12} \mathrm{O}_{40}$ salt [49].

Corrosion of platinum flag (counter electrode) in $0.5 \mathrm{~mol} \mathrm{dm}^{-3} \mathrm{H}_{2} \mathrm{SO}_{4}$ containing $5 \mathrm{mmol} \mathrm{dm}{ }^{-3}$ solution of $\mathrm{KCl}$ has resulted in the deposition of Pt nanoparticles on layers made from $\mathrm{Cs}_{2.5} \mathrm{H}_{0.5} \mathrm{PW}_{12} \mathrm{O}_{40} /$ Vulcan or bare Vulcan deposited on the surface of RDE electrode. The presence of $\mathrm{Cl}^{-}$in the electrolyte enables dissolution of platinum due to the decrease of the Nernst potential at which Pt undergoes corro$\operatorname{sion}\left(E^{0}=1.2 \mathrm{~V}\right)$ according to the equations [51]:

$$
\begin{array}{ll}
\mathrm{PtCl}_{6}^{2-}+2 \mathrm{e}^{-} \leftrightarrow \mathrm{PtCl}_{4}^{2-}+2 \mathrm{Cl}^{-} & 0.68 \mathrm{~V} \text { vs.RHE } \\
\mathrm{PtCl}_{4}^{2-}+2 \mathrm{e}^{-} \leftrightarrow \mathrm{Pt}+4 \mathrm{Cl}^{-} & 0.73 \mathrm{~V} \text { vs.RHE }
\end{array}
$$

Figure 2 illustrates representative cyclic voltammetric responses of composite film, $\mathrm{Cs}_{2.5} \mathrm{H}_{0.5} \mathrm{PW}_{12} \mathrm{O}_{40} /$ Vulcan, before (a) and after (b) Pt counter electrode corrosion. It is apparent that after the experiment, large increase of voltammetric currents in hydrogen adsorption/desorption region, characteristic for noble metal, was observed which implies effective deposition of Pt.

In order to comment on the effectiveness of the proposed approach to dope the composite film (and Vulcan) with Pt nanoparticles and to get information about such parameters as electrochemically active area, dimensions, and approximate Pt loading that may be obtained, alternative methods to detect Pt have been used. They include both HRTEM and CO-stripping.

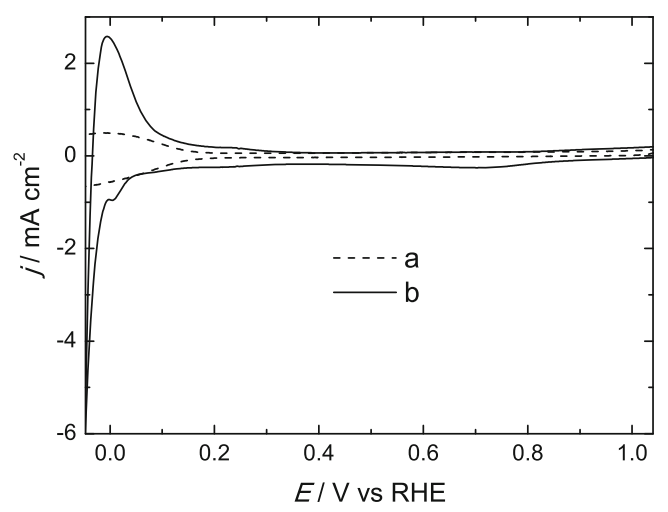

Fig. 2 Cyclic voltammograms recorded for $\mathrm{Cs}_{2.5} \mathrm{H}_{0.5} \mathrm{PW}_{12} \mathrm{O}_{40} /$ Vulcan deposited onto a GC electrode before $(a)$ and after $(b)$ corrosion process performed in the assembly with platinum flag as counter electrode. Electrolyte, nitrogen-saturated $0.5 \mathrm{~mol} \mathrm{dm}^{-3} \mathrm{H}_{2} \mathrm{SO}_{4}$. Scan rate, $50 \mathrm{mV} \mathrm{s}^{-1}$
Figure 3 shows HRTEM images of Pt nanoparticles electrodeposited on GC electrode covered with composite and pure Vulcan carbon. It is evident that, in the case of the saltcontaining system, nanoparticles of Pt have diameters about 1-2 nm (Fig. 3a), while for the catalytic layer containing only Vulcan, the platinum particles have dimensions of ca. $4 \mathrm{~nm}$ (Fig. 3b). Probable explanation of the different size of obtained particles may be that, in the case of the $\mathrm{Cs}_{2.5} \mathrm{H}_{0.5} \mathrm{PW}_{12} \mathrm{O}_{40^{-}}$ containing composite, $\mathrm{Pt}$ deposition occurs inside the nanochannels of the porous tertiary structure of the salt while, in the case of pure Vulcan, the particles grow on the surface lacking of any physical barrier, thus permitting their agglomeration, and consequently, larger dimensions.

The electrochemically active area of Pt electrodes is usually measured using the hydrogen adsorption/desorption peaks. In our case, this method could not be applied because Cs salt is electroactive in the same potential region (see Fig. 2) and, hence, the integrated areas under the peaks contain the contributions due to the reduction of the matrix itself. It is well established in the literature that $\mathrm{CO}$ adsorbs on Pt thus poisoning its surface. Adsorbed $\mathrm{CO}$ can be stripped from the $\mathrm{Pt}$ surface at potentials in the range $0.7-0.9 \mathrm{~V}$ vs. RHE. The
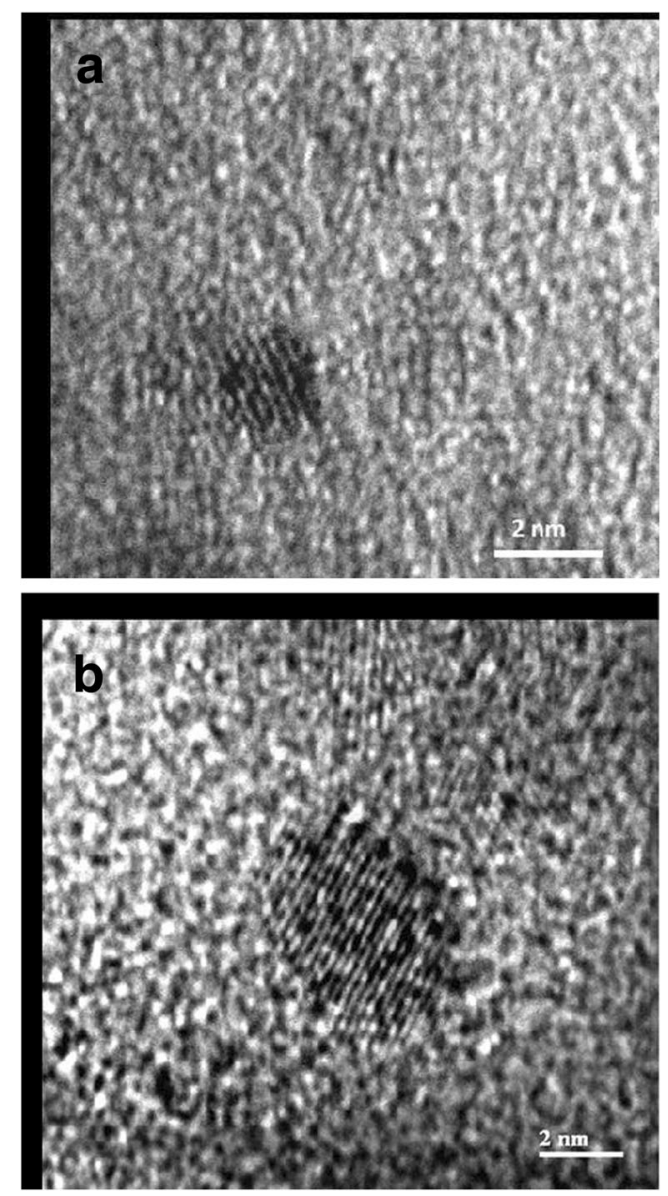

Fig. 3 HRTEM images of Pt nanoparticles generated during corrosion of $\mathrm{Pt}$ counter electrode within the composite of $\mathrm{Cs}_{2.5} \mathrm{H}_{0.5} \mathrm{PW}_{12} \mathrm{O}_{40}$ /Vulcan (a) and onto bare Vulcan (b) 
charge corresponding to one monolayer of adsorbed $\mathrm{CO}$ is equal to $0.484 \mathrm{mC} \mathrm{cm}^{-2}$ [47, 48]. Hence, by measuring the charge under the stripping peak, after subtraction of the background currents, the electrochemically active area (EAS) of platinum can be obtained using the formula:

$\mathrm{EAS}=\frac{Q_{\mathrm{CO}}}{0.484}$

where $Q_{\mathrm{CO}}$ is the measured charge.

Solid lines (curves a) in Fig. 4a, b illustrate voltammograms obtained at $20 \mathrm{mV} \mathrm{s}^{-1}$ for the composite electrode, i.e., Pt- $\mathrm{Cs}_{2.5} \mathrm{H}_{0.5} \mathrm{PW}_{12} \mathrm{O}_{40} /$ Vulcan, before (a) and after (b) $\mathrm{CO}$ adsorption. The peak relative to hydrogen desorption present in the pristine electrode (Fig. 4a, curve a) is completely absent after $\mathrm{CO}$ adsorption (Fig. 4b, curve a). This testifies that the entire $\mathrm{Pt}$ surface is completely blocked by $\mathrm{CO}$. The stripping of $\mathrm{CO}$ appearing at about $0.85 \mathrm{~V}$ is very well-defined (Fig. $4 \mathrm{~b}$, curve a). The computed charge under the peak $\left(Q_{\mathrm{CO}}\right)$, for the catalytic layer obtained after Pt corrosion, was equal to $0.221 \mathrm{mC}$; thus, the calculated electrochemically active area (EAS) was equal to $0.456 \mathrm{~cm}^{2}$.

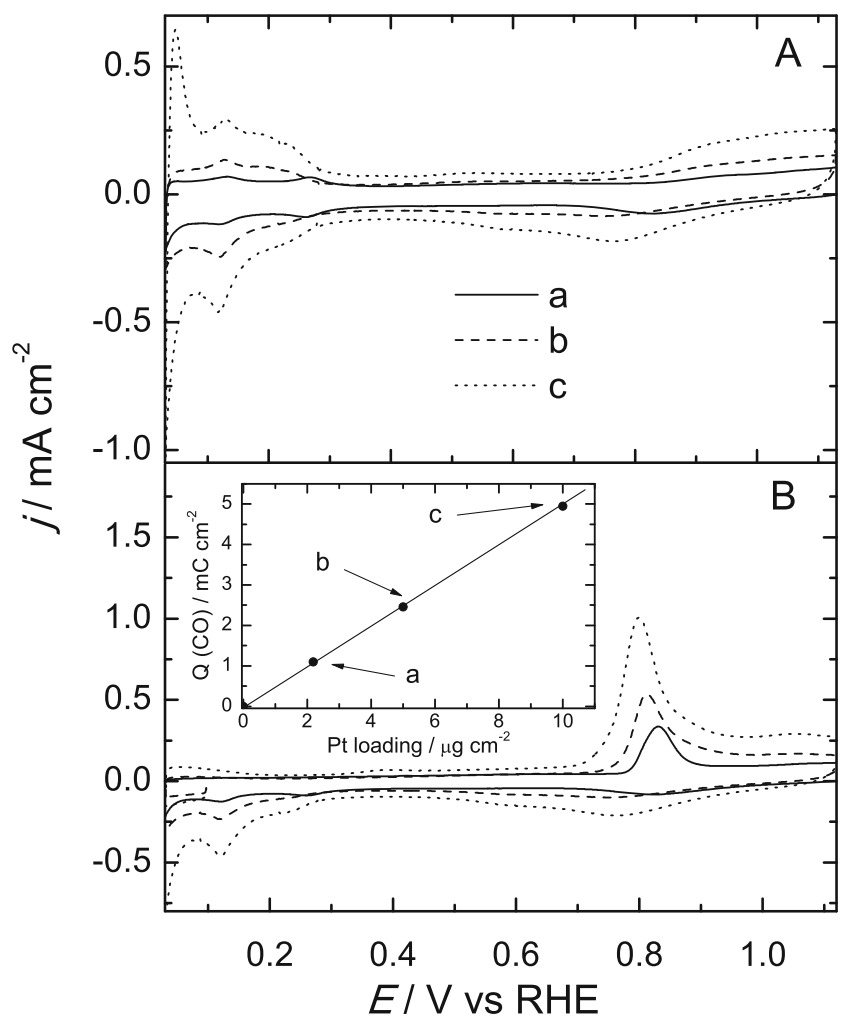

Fig. 4 a Cyclic voltammograms of $\mathrm{Pt}_{-} \mathrm{Cs}_{2.5} \mathrm{H}_{0.5} \mathrm{PW}_{12} \mathrm{O}_{40} /$ Vulcan $(a), \mathrm{Pt} /$ $\mathrm{C}\left(L_{\mathrm{Pt}}=5 \mu \mathrm{g} \mathrm{cm}{ }^{-2}\right)$ admixed with $\mathrm{Cs}_{2.5} \mathrm{H}_{0.5} \mathrm{PW}_{12} \mathrm{O}_{40}(b)$ and $\mathrm{Pt} / \mathrm{C}\left(L_{\mathrm{Pt}}=\right.$ $10 \mu \mathrm{g} \mathrm{cm}^{-2}$ ) admixed with $\mathrm{Cs}_{2.5} \mathrm{H}_{0.5} \mathrm{PW}_{12} \mathrm{O}_{40}(c)$; b oxidation of $\mathrm{CO}$ adsorbed ad-layers on $\mathrm{Pt}$ within the films described above recorded in the argon saturated $0.5 \mathrm{~mol} \mathrm{dm}^{-3} \mathrm{H}_{2} \mathrm{SO}_{4}$. Scan rate, $20 \mathrm{mV} \mathrm{s}^{-1}$; inset shows calibration curve plotted on the basis of experiments presented in $\mathbf{b}$
Knowing dimensions of Pt nanoparticles and assuming their spherical shape, it was possible to calculate their specific surface area $(S)$ using the following equation [52-54]:

$S=\frac{6 \times 10^{3}}{\rho \times d}$

where $d$ is the mean particle size in nanometer (estimated from HRTEM images) and $\rho$ is the density of Pt metal $\left(21.4 \mathrm{~g} \mathrm{~cm}^{-3}\right)$. Assuming that all nanoparticles have dimension ca. $2 \mathrm{~nm}$ and excluding the existence of aggregated nanoparticles, obtained surface area for one nanoparticle is equal to $140.18 \mathrm{~m}^{2} \mathrm{~g}^{-1}$. The consideration of obtained value of EAS, received from CO-stripping measurements (assuming $100 \%$ coverage), and the value of $S$ for one particle has enabled us to calculate the approximate loading of platinum in the catalytic layer by applying following dependence:

$L_{\mathrm{Pt}}=\frac{\mathrm{EAS}}{S \times A}$

where $A$ is the area of the RDE electrode $\left(A=0.1256 \mathrm{~cm}^{2}\right)$. According to this equation, the calculated Pt loading was $2.6 \mu \mathrm{g} \mathrm{cm}^{-2}$. This value is only a rough estimation. Nevertheless, the value very well agrees with the one found from calibration curve, plotted on the basis of CO-stripping measurements conducted for commercial Pt10 \%/Vulcan XC-72 carbon modified with $\mathrm{Cs}_{2.5} \mathrm{H}_{0.5} \mathrm{PW}_{12} \mathrm{O}_{40}$ salt concerning two loadings of Pt, namely 5 and $10 \mu \mathrm{g} \mathrm{cm}^{-2}$ (Fig. $4 \mathrm{a}$, b, curves b and c, respectively). The admixing of well-characterized commercial catalyst with $\mathrm{Cs}_{2.5} \mathrm{H}_{0.5} \mathrm{PW}_{12} \mathrm{O}_{40}$ has aimed at achieving similar environment in the vicinity of platinum as in synthesized sample. The dependence of the total voltammetric charge in the $\mathrm{CO}$ adsorption region determined for the electrodes vs. Pt loading is shown in the inset of Fig. 4b. The curve can be fitted reasonably well by a straight line with zero intercept confirming the validity of the method [10]. The loading of Pt, obtained for composite catalytic layer (i.e., Pt$\mathrm{Cs}_{2.5} \mathrm{H}_{0.5} \mathrm{PW}_{12} \mathrm{O}_{40}$ /Vulcan) performed by corrosion of $\mathrm{Pt}$ counter electrode, is ca. $2.3 \mu \mathrm{g} \mathrm{cm}^{-2}$ (point a in the inset of Fig. 4b). Taking into consideration that CO-stripping method could be burdened with large errors because it enables determination of Pt surface accessible for $\mathrm{CO}$ molecules as well as by assuming that somewhere between 50 to $100 \%$ of $\mathrm{Pt}$ present in the channels of $\mathrm{Cs}_{2.5} \mathrm{H}_{0.5} \mathrm{PW}_{12} \mathrm{O}_{40}$ chemisorbs carbon monoxide, we can conclude that Pt loading in the composite is roughly on the level of $2-5 \mu \mathrm{g} \mathrm{cm}^{-2}$.

Since the ultimate goal of our research was to produce $\mathrm{Pt}$ nanostructures exhibiting promising electrocatalytic properties, we have examined reactivity of platinum nanoparticles (obtained via anodic dissolution of Pt counter electrode) imbedded in $\mathrm{Cs}_{2.5} \mathrm{H}_{0.5} \mathrm{PW}_{12} \mathrm{O}_{40}$ /Vulcan matrix towards reduction of oxygen. RDE measurements (Fig. 5) for the oxygen reduction at (a) $\mathrm{Cs}_{2.5} \mathrm{H}_{0.5} \mathrm{PW}_{12} \mathrm{O}_{40}$-containing and (b) 


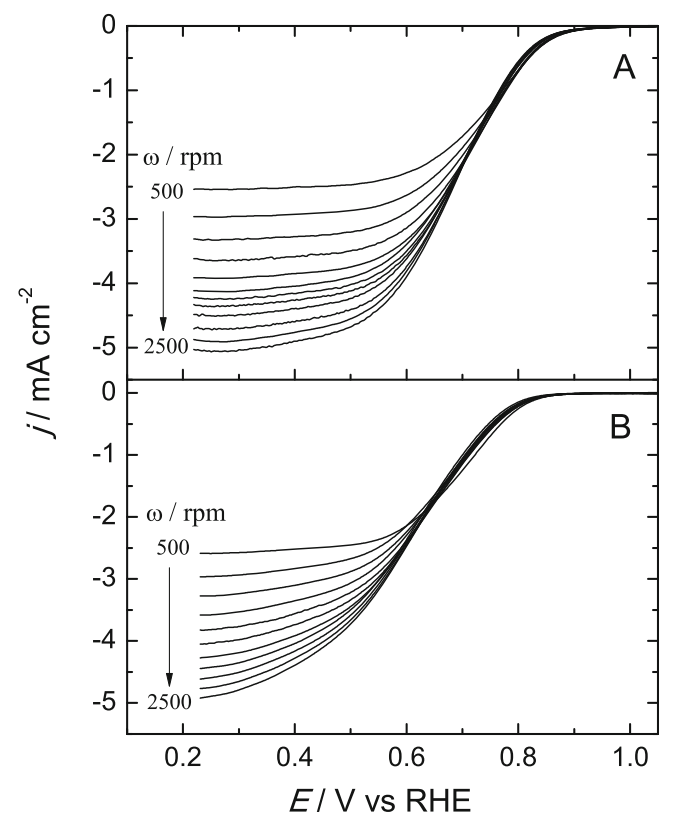

Fig. 5 RDE responses (recorded at different rotation rates) for oxygen reduction at Pt-containing films of $\mathbf{a} \mathrm{Cs}_{2.5} \mathrm{H}_{0.5} \mathrm{PW}_{12} \mathrm{O}_{40} /$ Vulcan and $\mathbf{b}$ Vulcan. Electrolyte, oxygen saturated $0.5 \mathrm{~mol} \mathrm{dm}^{-3} \mathrm{H}_{2} \mathrm{SO}_{4}$. Scan rate, $10 \mathrm{mV} \mathrm{s}^{-1}$

$\mathrm{Cs}_{2.5} \mathrm{H}_{0.5} \mathrm{PW}_{12} \mathrm{O}_{40}$-free catalytic layers obtained after corrosion of Pt were performed at different rotation rates (ranging from 500 to 2,500 rpm). Both sets of RDE responses are welldefined. Figure 6 shows comparison of RDE voltammograms recorded at the same rotation rate- $-1,600 \mathrm{rpm}$. It can be observed that for catalytic layer containing $\mathrm{Cs}_{2.5} \mathrm{H}_{0.5} \mathrm{PW}_{12} \mathrm{O}_{40}$ (curve $b$ ), the polarization $\mathrm{E}-\mathrm{j}$ curve is shifted towards more positive values of potential, e.g., about $60 \mathrm{mV}$ at $2.5 \mathrm{~mA} \mathrm{~cm}^{-2}$, in comparison to $\mathrm{Cs}_{2.5} \mathrm{H}_{0.5} \mathrm{PW}_{12} \mathrm{O}_{40}$-free catalyst (curve a). The potential effect is almost perfectly reproducible within $\pm 5 \mathrm{mV}$. On the whole, obtained results are consistent with the view that the deposition of $\mathrm{Pt}$ within the matrix containing $\mathrm{Cs}_{2.5} \mathrm{H}_{0.5} \mathrm{PW}_{12} \mathrm{O}_{40}$ results in fabrication of smaller Pt nanoparticles when compared to $\mathrm{Cs}_{2.5} \mathrm{H}_{0.5} \mathrm{PW}_{12} \mathrm{O}_{40}$-free system

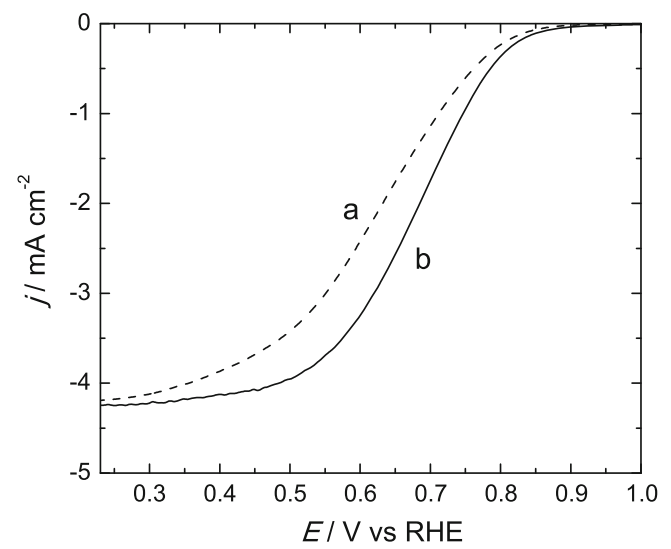

Fig. 6 Comparison of RDE voltammograms recorded for oxygen reduction at Pt containing films of $\mathrm{Cs}_{2.5} \mathrm{H}_{0.5} \mathrm{PW}_{12} \mathrm{O}_{40} /$ Vulcan $(b)$ and Vulcan (a). Rotation rate, 1,600 rpm. Other parameters as for Fig. 5 (confirmed by HRTEM images presented in Fig. 3) leading to better utilization and, consequently, higher reactivity of noble metal centers towards reduction of oxygen. Moreover, high surface acidity of the salt (which acid strength remains on similar level as in original heteropolytungstate) and proton mobility, which are necessary for effective reduction of oxygen to water, certainly also play an important role in enhancing catalytic activity of Pt nanoparticles. Besides, by analogy to the behavior of tungsten oxide and heteropolytungstates [12-22], it is reasonable to expect that $\mathrm{Cs}_{2.5} \mathrm{H}_{0.5} \mathrm{PW}_{12} \mathrm{O}_{40}$ would also interact specifically with platinum catalytic centers.

In order to assign the rate-determining step in the whole electrocatalytic reaction proceeding at composite material, the experiments in electrolyte with lower concentration of oxygen have also been conducted. Figure 7 a shows representative RDE voltammetric responses (at 1,600 rpm) for glassy carbon electrode modified with $\mathrm{Pt}_{-} \mathrm{Cs}_{2.5} \mathrm{H}_{0.5} \mathrm{PW}_{12} \mathrm{O}_{40}$ /Vulcan recorded in (a) argon-, (b) air- and (c) oxygen-saturated solutions. Koutecky-Levich reciprocal dependencies plotted for oxygen reduction process in air- and oxygen-saturated electrolyte at potential $0.5 \mathrm{~V}$ versus RHE are presented in Fig. $7 \mathrm{~b}$. The positive intercepts clearly indicate kinetic limitations associated with the catalytic film. The inverse proportionalities of the slopes and intercepts with concentration of oxygen imply that the currents are not limited by charge transport within the layer, and only such factors as transport of oxygen in the solution or at higher rotation rates the dynamics of the catalytic reaction are rate-determining steps [55]. It seems that highly porous structure of the matrix (especially large amount of mesopores) ensures easy access of electrolyte and oxygen molecules to catalytic nanocenters.

Furthermore, to verify that the cesium heteropolytungstate matrix may perform other important function in the composite material, simple voltammetric experiments in argon-saturated $0.5 \mathrm{~mol} \mathrm{dm}^{-3} \mathrm{H}_{2} \mathrm{SO}_{4}$ containing $\mathrm{H}_{2} \mathrm{O}_{2}$ at $10 \mathrm{mmol} \mathrm{dm}^{-3}$ level were conducted at $\mathrm{GC}$ electrode covered with the layers of

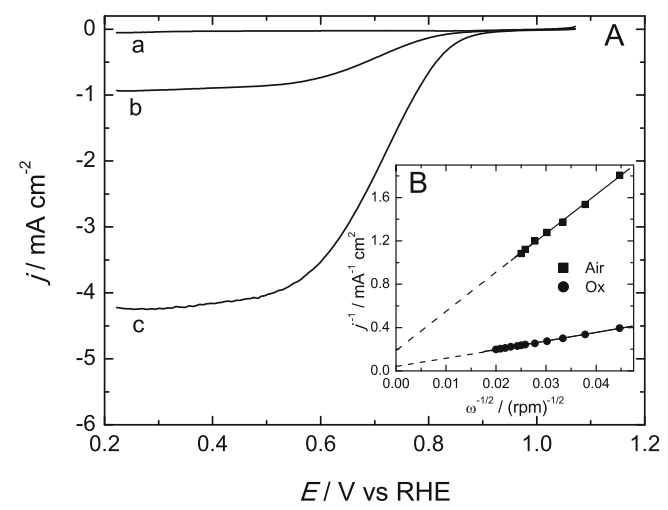

Fig. 7 a RDE voltammograms recorded at 1,600 rpm for Pt$\mathrm{Cs}_{2.5} \mathrm{H}_{0.5} \mathrm{PW}_{12} \mathrm{O}_{40} /$ Vulcan in $(a)$ argon-, $(b)$ air-, and $(c)$ oxygen-saturated electrolyte. Electrolyte, $0.5 \mathrm{~mol} \mathrm{dm}{ }^{-3} \mathrm{H}_{2} \mathrm{SO}_{4}$. Scan rate, $10 \mathrm{mV} \mathrm{s}^{-1}$. b Koutecky-Levich plots at potential $0.5 \mathrm{~V}$ 
$\mathrm{Cs}_{2.5} \mathrm{H}_{0.5} \mathrm{PW}_{12} \mathrm{O}_{40} /$ Vulcan and bare Vulcan (Fig. 8). It is evident that the film consisted of cesium heteropolyacid salt admixed with Vulcan exhibits some electrocatalytic activity towards reduction of hydrogen peroxide even at potentials as positive as $0.65 \mathrm{~V}$ (Fig. 8a). On the other hand, in the case of bare Vulcan, only residual catalytic currents at positive potentials could be observed (Fig. 8b). Thus, $\mathrm{Cs}_{2.5} \mathrm{H}_{0.5} \mathrm{PW}_{12} \mathrm{O}_{40}$ can be viewed as matrix able to decompose, at least to some extent, hydrogen peroxide intermediate generated during oxygen reduction at platinum traces where the average distance between metal nanoparticles could be large, and therefore the effective reduction of oxygen molecules directly to water could be hindered.

In terms of practical applications of the catalysts in fuel cells, the very important matter is their durability. Therefore we conducted preliminary stability tests of the composite layer (Pt-Cs ${ }_{2.5} \mathrm{H}_{0.5} \mathrm{PW}_{12} \mathrm{O}_{40} /$ Vulcan) deposited on RDE electrode by recording voltammetric responses in oxygen-saturated $0.5 \mathrm{~mol} \mathrm{dm}^{-3} \mathrm{H}_{2} \mathrm{SO}_{4}$ (at scan rate equal to $10 \mathrm{mV} \mathrm{s}^{-1}$ and rotation rate- $1,600 \mathrm{rpm}$ ) during extended time. On the basis of obtained results, we plotted the dependence of catalytic current density in the function of time of the experiment. It is apparent from Fig. 9 that the system is very stable - its performance did not undergo meaningful depletion during over $6 \mathrm{~h}$ of operation.

Finally, we also performed experiments to determine catalytic activity of proposed system towards reaction proceeding in anodic compartment of the Polymer Electrolyte Fuel Cell (PEMFC), namely hydrogen oxidation. Figure 10 presents the hydrogen oxidation polarization curves recorded at several

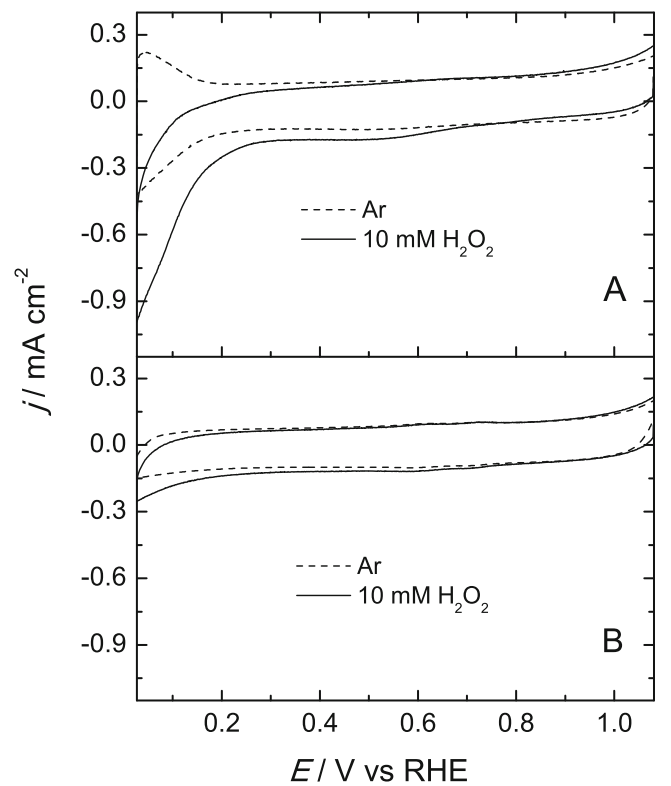

Fig. 8 Cyclic voltammetric responses for $\mathrm{H}_{2} \mathrm{O}_{2}\left(10 \mathrm{mmol} \mathrm{dm}^{-3}\right)$ reduction (solid lines) at glassy carbon electrode modified with a $\mathrm{Cs}_{2.5} \mathrm{H}_{0.5} \mathrm{PW}_{12} \mathrm{O}_{40} /$ Vulcan and b Vulcan. Dashed lines represent responses of the layers in argon-saturated $\mathrm{H}_{2} \mathrm{O}_{2}$-free $0.5 \mathrm{~mol} \mathrm{dm}^{-3} \mathrm{H}_{2} \mathrm{SO}_{4}$ electrolyte. Scan rate, $10 \mathrm{mVs}^{-1}$

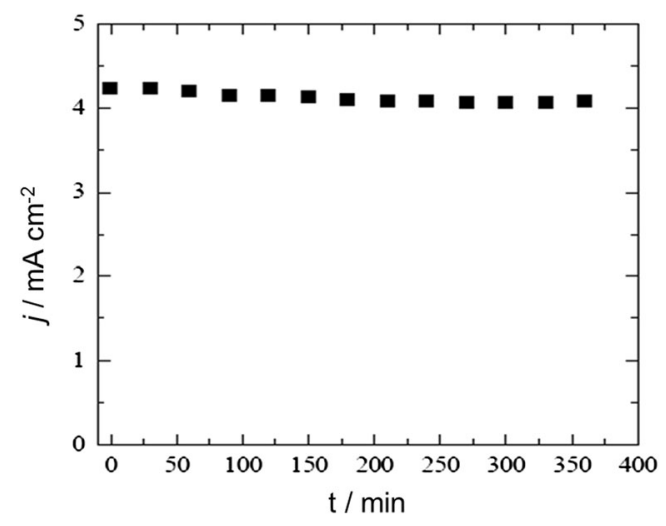

Fig. 9 The results of stability test conducted for Pt-containing $\mathrm{Cs}_{2.5} \mathrm{H}_{0.5} \mathrm{PW}_{12} \mathrm{O}_{40} /$ Vulcan. Details can be found in the text

rotation speeds $(1,300 \mathrm{rpm} \leq \omega \leq 2,500 \mathrm{rpm})$ in $0.5 \mathrm{~mol} \mathrm{dm}^{-3}$ $\mathrm{H}_{2} \mathrm{SO}_{4}$ on the following catalytic layers: (a) Pt$\mathrm{Cs}_{2.5} \mathrm{H}_{0.5} \mathrm{PW}_{12} \mathrm{O}_{40} /$ Vulcan and (b) Pt-Vulcan (for comparison). The anodic potential was limited to $100 \mathrm{mV}$ because the limiting currents reach a constant value at ca. $80 \mathrm{mV}$ in the case of both catalytic layers. Also, the coupled hydrogen adsorption-electron transfer steps of the reaction are observed at potentials only below $50 \mathrm{mV}$. Current densities recorded for catalytic film containing $\mathrm{Cs}_{2.5} \mathrm{H}_{0.5} \mathrm{PW}_{12} \mathrm{O}_{40}$ are higher than those obtained for layer containing only Vulcan particles (compare curves $\mathrm{a}$ and $\mathrm{b}$ recorded at 2,500 rpm in the inset of Fig. 10). Similarly to the discussion concerning oxygen reduction process, present observations can be explained by formation of smaller Pt nanoparticles not only on the surfaces but also possibly inside the channels of micro-mesoporous

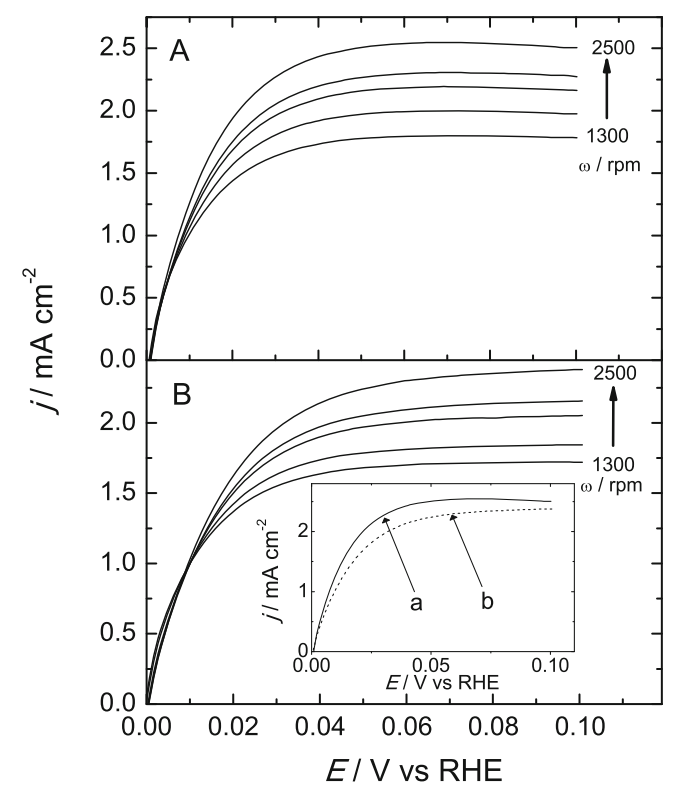

Fig. 10 Rotating disk polarization curves (at rotation rates in the range of 1,300-2,500 rpm) for the hydrogen oxidation recorded at the following catalytic layers: a Pt-Cs ${ }_{2.5} \mathrm{H}_{0.5} \mathrm{PW}_{12} \mathrm{O}_{40} /$ Vulcan and b Pt-Vulcan. Inset shows comparison of the curves recorded at 2,500 rpm. Electrolyte: nitrogen-saturated $0.5 \mathrm{~mol} \mathrm{dm}^{-3} \mathrm{H}_{2} \mathrm{SO}_{4}$. Scan rate, $10 \mathrm{mV} \mathrm{s}^{-1}$ 
structure of the matrix which prevents their agglomeration and results in the increase of the number of accessible reactive sites. Specific activating interactions between heteropolytungstate units and Pt nanocenters cannot be either excluded.

\section{Conclusions}

An objective of the present work was to explore a unique simple preparation method of the electrocatalytic system containing highly dispersed platinum nanoparticles immobilized in stable zeolitic-type matrix by electrochemical deposition method. Corrosion of platinum counter electrode enabled embedding of platinum nanocenters into the mesoporous $\mathrm{Cs}_{2.5} \mathrm{H}_{0.5} \mathrm{PW}_{12} \mathrm{O}_{40}$ solid superacid (admixed with Vulcan support) deposited on a working electrode. Obtained composite material containing ultra-low noble metal loading demonstrated superior catalytic activity during oxygen reduction in terms of shifting the process potential towards more positive values when compared to $\mathrm{Cs}_{2.5} \mathrm{H}_{0.5} \mathrm{PW}_{12} \mathrm{O}_{40}$-free system examined under analogous conditions. The system was also probed during the hydrogen oxidation process - higher catalytic current densities were observed in comparison to Pt nanoparticles deposited on bare carbon support. The enhanced activity of the catalytic film in both mentioned above processes could be principally assigned to such properties of applied matrix as mesoporous structure and ability to immobilize and stabilize very small nanoparticles leading to better utilization of noble metal centers. Furthermore, specific interactions of heteropolytungstic units with platinum are also highly probable. In addition, high mobility of the surface protons in the salt as well as partial decomposition of the intermediate (hydrogen peroxide) likely also plays an important role in enhancing catalytic activity of Pt nanoparticles towards oxygen reduction.

Acknowledgments The Polish group is grateful for the support from National Science Centre (Poland) under grant N N204 269840. The research has been also carried out within the NUME Project "Development of composite proton membranes and of innovative electrode configurations for polymer electrolyte fuel cells" (MIUR, FISR 2003). We are grateful to Eric Larquet, Agnieszka Witkowska, and Marco Minicucci for HRTEM investigations.

Open Access This article is distributed under the terms of the Creative Commons Attribution License which permits any use, distribution, and reproduction in any medium, provided the original author(s) and the source are credited.

\section{References}

1. Watanabe M, Saegusa S, Stonehart P (1988) Chem Lett Jpn 9:14871490

2. Mukerjee S, Srinivasan S, Soriaga MP, McBreen J (1995) J Phys Chem 99:4577-4589
3. Paulus UA, Wokaun A, Scherer GG, Schmidt TJ, Stamenkovic V, Markovic NM, Ross PN (2002) Electrochim Acta 47:3787-3798

4. Inoue H, Brankovic SR, Wang JX, Adzic RR (2002) Electrochim Acta 47:3777-3785

5. Anderson AB, Roques J, Mukerjee S, Murthi VS, Marcovic NM, Stamenkovic V (2005) J Phys Chem B 109:1198-1203

6. Vogel W, Lundquist J, Ross P, Stonehart P (1975) Electrochim Acta 20:79-93

7. Vork FTA, Janssen LJJ, Barendrecht E (1986) Electrochim Acta 31: $1569-1575$

8. Mello RMQ, Ticianelli EA (1997) Electrochim Acta 42:1031-1039

9. Maruyama J, Inaba M, Katakura K, Ogumi Z, Takehara Z (1998) J Electroanal Chem 447:201-209

10. Schmidt TJ, Gasteiger HA, Stäb GD, Urban PM, Kolb M, Behm RJ (1998) J Electrochem Soc 145:2354-2358

11. Moss R (1981) Catalysis 4:131

12. Kulesza PJ, Faulkner LR (1989) J Electroanal Chem 259:81-98

13. Kulesza PJ, Grzybowska B, Malik MA, Galkowski MT (1997) J Electrochem Soc 144:1911-1917

14. Shen PK, Tseung ACC (1994) J Electrochem Soc 141:3082-3089

15. Shukla AK, Ravikumar MK, Arico AS, Candiano G, Antonucci V, Giordano N, Hamnett A (1995) J Appl Electrochem 25:52-532

16. Shim J, Lee CR, Lee HK, Lee JS, Cairns EJ (2001) J Power Sources 102:172-177

17. Lewera A, Timperman L, Roguska A, Alonso-Vante N (2011) J Phys Chem C 115:20153-20159

18. Timperman L, Lewera A, Vogel W, Alonso-Vante N (2010) Electrochem Commun 12:1772-1775

19. Savadogo O, Beck P (1996) J Electrochem Soc 143:3842-3846

20. Wlodarczyk R, Chojak M, Miecznikowski K, Kolary A, Kulesza PJ, Marassi R (2006) J Power Sources 159:802-809

21. Wlodarczyk R, Kolary-Zurowska A, Marassi R, Chojak M, Kulesza PJ (2007) Electrochim Acta 52:3958-3964

22. Chojak M, Kolary-Zurowska A, Wlodarczyk R, Miecznikowski K, Karnicka K, Palys B, Marassi R, Kulesza PJ (2007) Electrochim Acta 52:5574-5581

23. Ingersoll D, Kulesza PJ, Faulkner LR (1994) J Electrochem Soc 141: 140-147

24. Savadogo O, Essalik A (1994) US Patent NS 5:298

25. Kuo MC, Stanis RJ, Ferrell JR III, Turner JA, Herring AM (2007) Electrochim Acta 52:2051-2061

26. Stanis RJ, Kuo MC, Rickett AJ, Turner JA, Herring AM (2008) Electrochim Acta 53:8277-8286

27. Nakamura O, Kodama T, Ogino L, Miyake Y (1977) Jpn Pat 4:024-036

28. Giordano N, Staiti P, Hocevar S, Arico AS (1996) Electrochim Acta 41:397-403

29. Ramani V, Kunz HR, Fenton JM (2005) Electrochim Acta 50:11811187

30. Ramani V, Kunz HR, Fenton JM (2005) J Membr Sci 266:110-114

31. Koyano G, Ueno K, Misono M (1999) Appl Catal A Gen 181:267275

32. Soled S, Miseo S, McVicker G, Gates WE, Gutierrez A, Paes J (1997) Catal Today 36:441-450

33. Okuhara T, Watanabe H, Nishimura T, Inumaru K, Misono M (2000) Chem Mater 12:2230-2238

34. Lee KY, Oishi S, Igarashi H, Misono M (1997) Catal Today 33:183189

35. Soled S, Miseo S, McVicker G, Gates WE, Gutierrez A, Paes J (1996) Chem Eng J 64:247-254

36. Mizuno N, Misono M (1998) M Chem Rev 98:199-217

37. Amirinejad M, Madaeni SS, Rafiee E, Amirinejad S (2011) J Membr Sci 377:9-98

38. Wang L, Yi BL, Zhang HM, Xing DM (2007) Electrochim Acta 52: 5479-5483

39. Zhao D, Yi BL, Zhang HM, Yu HM, Wang L, Ma YW, Xing DM (2009) J Power Sources 190:301-306 
40. Dsoke S, Moretti A, Giuli G, Marassi R (2011) Int J Hydrog Energy 36:8098-8102

41. Dsoke S, Kolary-Zurowska A, Zurowski A, Mignini P, Kulesza PJ, Marassi R (2011) J Power Sources 196:10591-10600

42. Scrosati B, Marassi R, Kolary A, Zurowski A, Kulesza PJ, Dsoke S (2007) Catalizzatori a basso contenuto in Pt per celle a combustibile' Brevetto Italiano. RM2007A000228

43. Scrosati B, Marassi R, Kolary A, Zurowski A, Kulesza PJ, Dsoke S (2008) Catalysts having low Pt content for fuel cells. PCT/IB2008/ 051462

44. Kulesza PJ, Lu W, Faulkner LR (1992) J Electroanal Chem 336:35-44

45. Essayem N, Tong YY, Jobic H, Vedrine JC (2000) Appl Catal A Gen 194:109-122

46. Essayem N, Ben Taarit Y, Gayraud PY, Sapaly G, Naccache C (2001) J Catal 204:157-162

47. Pozio A, Francesco M, Cemmi A, Cardellini F, Giorgi L (2002) J Power Sources 105:13-19
48. Weaver MJ, Chang SC, Leung LWH, Jiang X, Rubel M, Szklarczyk M, Zurawski D, Wieckowski A (1992) J Electroanal Chem 327:247260

49. Zurowski A, Kolary-Zurowska A, Dsoke S, Barczuk PJ, Marassi R, Kulesza PJ (2010) J Electroanal Chem 649:238-247

50. Kulesza PJ, Karnicka K, Miecznikowski K, Chojak M, Kolary A, Barczuk PJ, Tsirlina G, Czerwinski W (2005) Electrochim Acta 50: $5155-5162$

51. Latimer WM (1952) The oxidation states of the elements and their potentials in aqueous solutions. Prentice-Hall, New York

52. Babić BM, Vračar LM, Radmilović V, Krstajić NV (2006) Electrochim Acta 51:3820-3826

53. Rand DAJ, Woods R (1972) J Electroanal Chem 35:209-218

54. Gloaguen F, Léger JM, Lamy C (1997) J Appl Electrochem 27:10521060

55. Andrieux CP, Dumas-Bouchiat JM, Saveant JM (1982) J Electroanal Chem 131:1-35 